\title{
Analysis of Reliability-based Systems of 20 kV Distribution Network Disturbance on PT. PLN Rayon Panam
}

\author{
Slamet Suripto ${ }^{* 1}$, Rahmat Adiprasetya Al Hasibi ${ }^{1}$, Kharisma Trinanda Putra ${ }^{2}$, Yessi Jusman ${ }^{1}$, \\ Muhammad Rusydi Al Aroffi ${ }^{1}$, Jamaaluddin ${ }^{3}$ \\ ${ }^{1}$ Department of Electrical Engineering, Faculty of Engineering, \\ Universitas Muhammadiyah Yogyakarta 55183 Bantul, Yogyakarta, Indonesia \\ ${ }^{2}$ College of Information and Electrical Engineering, Asia University \\ Liufeng Road 500, Wufeng District, Taichung City, Taiwan 41354 \\ ${ }^{3}$ Department of Electrical Engineering, Universitas Muhammadiyah Sidoarjo \\ Kampus 2 J1. Raya Gelam 250 Candi, Sidoarjo, East Java, Indonesia \\ *Corresponding author, e-mail: slametsuripto@umy.ac.id
}

\begin{abstract}
Electricity needs for each year have increased, this is due to an increase in people's lives. Reliability is an essential factor in the operation of a distribution system and is an essential factor in the continuity of the waiter to the consumer. Several parameters are used as a reference to measure the level of reliability of a distribution system, i.e., SAIFI (average interruption of frequency index system) and SAIDI (System of interruption Duration Index). In this study, it was also performed calculations EENS (Expected Energy Not Supplied). This calculation is done because of a disturbance at each feeder; there is an energy that can not be transmitted; it can happen losses. Based on the calculation and analysis that the reliability index is obtained, there are some feeder Rayon Panam categorized as not reliable because it has a high SAIFI value not following the target SPLN No. 68-2 1986 and IEEE std 1366-2003. Energy losses that can not be distributed annually sizeable each feeder. This fact indicates a feeder located at Panam Rayon considered less reliable, to the need for repairs and maintenance.
\end{abstract}

Keywords: Reliability, Interruption, Loss, SAIFI, SAIDI, EENS

\section{Introduction}

In the developing world today, electric energy is a very important aspect in life. Electrical energy is energy that is very important because it indirectly to the welfare of human life and also can affect the economic growth in modern times [1]. The higher the welfare of one's life, the higher the dependence on electrical energy sufficient and quality. Similarly, the more developed a industry, the role of electric energy will be even greater for industrial progress in the future [2].

Based on Law No.30 of 2009 on electricity power article 28, says that the license holders compulsory provision of electric power supply electric power that meets the applicable quality standards of reliability and provide the best possible service to customers and communities. This requires electricity providers to improve the quality of its products and services, so as to minimize outages to maintain customer satisfaction. PT. PLN (Persero) is the only State-Owned Enterprises engaged in the provision of services to the distribution of electrical power. With the development of technology, industry, and the increasing demand for electricity, it is in need of electrical energy supply and distribution excellence.

Distribution system reliability is the probability distribution of a component or system in fulfilling the functions required in a particular period. Increasing demand of electricity demand of electric power distribution system having a good level of reliability. In the distribution system, quality reliability can be seen from the length of the blackout and how often outage occurs in one unit of 
time, say in a year. With a level of reliability in accordance with the standards, community users can enjoy continuous electrical energy. To deliver electricity from the substation to load centers distribution system is required. A distribution system must have a certain reliability value, which depends on the reliability of the distribution system, which is obtained by calculating the index level of reliability. Reliability index is a measure of the reliability of the distribution system which is expressed in a probability scale. In the distribution of electricity, reliability level (Medium Voltage Network) JTM is necessary because these are factors that greatly affect the sustainability of the distribution of electrical energy to the consumer [3].

Here are some related research that is used as reference in this study, such as Ahmad Fajar Sayidul Yaom (2015) conducted a study on Analysis of System Reliability Electricity Distribution at PT PLN UPJ Rayon Brits, explained that only two feeders that have a value of SAIFI and SAIDI reliable. This means that at each substation must be analyzed in order to determine how much the value of reliability, because it affects the quality of the electricity supplied to customers [4].

In 2013, Okki doing research on network analysis $20 \mathrm{kV}$ medium voltage distribution system is by using RIA method. From the calculation with ETAP simulation SAIFI index is highest in zone 4 is 0.0363 times/year and greatest value indices SAIFI with RIA methods are in zone 1 is 0.0275 times/year. For the calculation of the required parameters single-line ETAP software diagram, capacity transformer, cable length and number of customers while RIA method requires a failure rate parameters [5].

Endra Heri Sulino UGM researches the Evaluation and Study of Reliability for Distribution System 4 kV Lex Plant Santan Terminal, Chevron Indonesia Company. He describes SAIFI, SAIDI, and CAIDI that those three things are a reliability index to determine whether the system is in the state according to expectations or not [6].

Based on related research, the authors are interested in doing research thesis titled "Analysis of Reliability-Based Systems and EENS (Expected energy not supplied) at 20kV Distribution Network Based Operation Disruption in PLN (Persero) Rayon Panam".

\section{Methods}

Flowchart for the study are presented in Fig. 1.

The steps undertaken to conduct this research can be obtained as a flow chart as follows:

1. Preliminary studies

Preliminary study is the first stage in the methodology of writing. At this stage of study and direct observation in the field to collect data in the PT. PLN rayon Panam.

\section{Problem Identification and Formulation}

After a preliminary study, the problem in the system area distribution Garuda Sakti electricity substation can be identified. Then the cause of the problem can be traced. In tracing the root cause of the problem, done by collecting data on the electricity distribution system.

Issues raised in this research as the topic is the analysis of Reliability-Based Systems and eens (Expected Energy Not Supplid) at 20kV Distribution Network by interruption of operations at PT. PLN (Persero) Rayon Panam.

\section{Literature review}

Studies conducted to obtain references references relating to searching for information information about the theory SAIDI, SAIFI, CAIDI, CAIFI, system of electric power transmission, distribution systems electrical components in substations, the reliability of the electricity distribution system $20 \mathrm{kV}$, standards reliability index values, methods and concepts that are relevant to the problem in this study. So with the information - that information can be used as a reference in the resolution of problems.

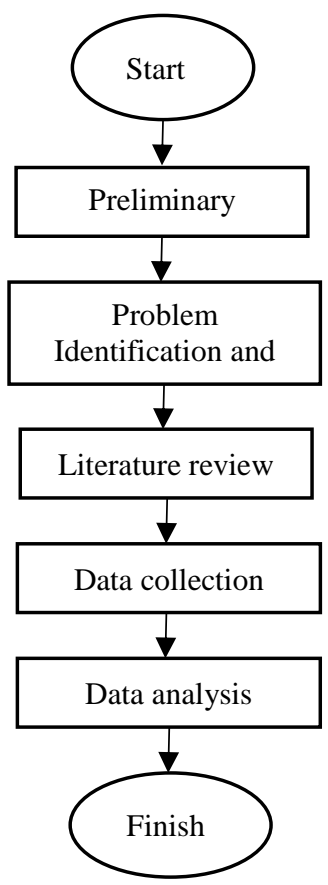

Fig. 1. Research flow chart

Journal of Electrical Technology UMY, Vol. 3 No. 3 


\section{Data collection}

The type of data in this study there are two (2) types, namely primary data and secondary data. Where the primary data can be obtained from the results of the study and direct observation of the research object. One of the methods used to obtain primary data is interview while in the field. The primary data required in this study between her, the amount of power transformer and the power capacity of each transformer at $150 / 20 \mathrm{kV}$ substations Garuda Sakti and Number of feeders 20 $\mathrm{kV}$ at $150 / 20 \mathrm{kV}$ substations Garuda Sakti Parent.

While data Secondary used in this study is a result of documentation which aims to obtain data data related to the thesis that will analyze how reliable power distribution system $20 \mathrm{kV}$ in each each feeder $20 \mathrm{kV}$ at the substation Garuda magic.

\section{Data analysis}

Based on the data obtained in the development of this research, the analysis will be performed to get the value of SAIDI, SAIFI, and CAIDI to know how big the actual reliability of the electrical distribution system in each feeder $20 \mathrm{kV}$ in 150/20 $\mathrm{kV}$ Substation Garuda Way. They also compare with the standard of reliability index value that is used in this thesis. The standard reliability index value used is the IEEE std 1366 - 2003, SPLN 68-2: 1986.

\section{Results and Discussion}

\section{III.1. Number of Subscribers Every Feeder of Rayon Panam}

To facilitate the observation and calculation, the data are grouped in subscribers feeder on Rayon Panam and obtained the total number of 130,000 customers. Data on the number of customers in Rayon Panam feeder can be seen in Table 1.

TABLE I

THE Number OF SubSCRIBERS OF EACH FEeder RAyOn PANAM

\begin{tabular}{clc}
\hline \hline No. & \multicolumn{1}{c}{ Feeder } & $\begin{array}{c}\text { Number of } \\
\text { Customers }\end{array}$ \\
\hline 1 & feeder 3 Coast Mirror & 6.896 \\
2 & feeder 4 Radish & 14.165 \\
3 & feeder 12 Kualu & 16.140 \\
4 & feeder 15 Herons Way & 19.062 \\
5 & feeder 18 Wildlife Works & 11.332 \\
6 & feeder 21 Tarai & 10.897 \\
7 & feeder 22 Stadium - UNRI & 15.639 \\
8 & feeder 7 Sukarno Hatta & 8.619 \\
9 & feeder 14 Panam & 8.692 \\
10 & feeder 26 Settlements & 9.884 \\
11 & feeder 25 Likes Work & 8.675 \\
\multicolumn{2}{c}{ TOTAL } \\
\hline \hline
\end{tabular}

\section{III.2. The length of each Feeder Rayon Panam}

To facilitate the observation and calculation of the amount of data grouped at Rayon Panam feeder length and the total number of subscribers gained $533.74 \mathrm{kms}$. Table 2 represents data in Rayon Panam feeder length.

TABLE II

THE LENGTH OF EACH FEEDER RAYON PANAM

\begin{tabular}{clccc}
\hline \hline No. & \multicolumn{1}{c}{ Name feeder } & LONG SUTM (KMS) & LONG SKTM (KMS) & TOTAL (SKTM + SUTM) \\
\hline 1 & feeder3 Coast Mirror & 92.3 & 2.5 & 94.8 \\
2 & feeder4 Radish & 35.91 & 5.2 & 41.11 \\
3 & feeder12 Kualu & 61.4 & 2,94 & 64.34 \\
4 & feeder15 Herons Way & 46.55 & 4.6 & 51.5 \\
5 & feeder18 Wildlife Works & 12.85 & 9.8 & 22.65 \\
6 & feeder21 Tarai & 71.8 & 14.38 & 86.18 \\
7 & feeder22 Stadium - UNRI & 17.2 & 9.98 & 27.18 \\
8 & feeder7 Sukarno Hatta & 14.7 & 6.6 & 21.3 \\
9 & feeder14 Panam & 22.73 & 2.6 & 25.33 \\
10 & feeder26 Settlements & 42.59 & 16.6 & 59.19 \\
11 & feeder25 Likes Work & 23.4 & 12.76 & 36.16 \\
\hline \multicolumn{2}{c}{ TOTAL } & 441.43 & 87.96 & 529.39 \\
\hline \hline
\end{tabular}


TABLE III

Disturbance of RAYON PANAM FeEdeR

\begin{tabular}{|c|c|c|c|}
\hline \multirow[b]{2}{*}{ No. } & \multirow[b]{2}{*}{ Name Of Feeder } & \multicolumn{2}{|c|}{ Disturbance Data Feeder } \\
\hline & & $\begin{array}{l}\text { Frequency/Numbers } \\
\text { Failure (Time) }\end{array}$ & $\begin{array}{l}\text { Duration Off } \\
\text { (Hour) }\end{array}$ \\
\hline 1 & feeder 3 Coast Mirror & 26 & 1.14 \\
\hline 2 & feeder 4 Radish & 11 & 5.44 \\
\hline 3 & feeder 12 Kualu & 52 & 21.95 \\
\hline 4 & feeder 15 Herons Way & 28 & 11.61 \\
\hline 5 & feeder 18 Wildlife Works & 25 & 9.92 \\
\hline 6 & feeder 21 Tarai & 35 & 14.84 \\
\hline 7 & feeder 22 Stadium - UNRI & 14 & 2.54 \\
\hline 8 & feeder 7 Sukarno Hatta & 15 & 4.2 \\
\hline 9 & feeder 14 Panam & 28 & 5.14 \\
\hline 10 & feeder 26 Settlements & 7 & 0.3 \\
\hline 11 & feeder 25 Likes Work & 12 & 5 \\
\hline
\end{tabular}

TABLE IV

SAIFI OF RAYON PANAM FEEDER

\begin{tabular}{rlcccc}
\hline \hline & & \multicolumn{4}{c}{ VALUE SAIFI } \\
\cline { 3 - 6 } No. & \multicolumn{1}{c}{ Name Feeder } & $\mathrm{Ni}$ & $\mathrm{Nt}$ & $\begin{array}{c}\lambda \mathrm{i} \\
\text { (times/year) }\end{array}$ & $\begin{array}{c}\text { SAIFI (times / } \\
\text { subscriber / year) }\end{array}$ \\
\hline 1 & feeder3 Coast Mirror & 6896 & 130.000 & 26 & 1.3792 \\
2 & feeder4 Radish & 14165 & 130.000 & 11 & 1.198577 \\
3 & feeder12 Kualu & 16140 & 130.000 & 52 & 6.456 \\
4 & feeder15 Herons Way & 19062 & 130.000 & 28 & 4.105662 \\
5 & feeder18 Wildlife Works & 11332 & 130.000 & 25 & 2.179231 \\
6 & feeder21 Tarai & 10897 & 130.000 & 35 & 2.933808 \\
7 & feeder22 Stadium - UNRI & 15639 & 130.000 & 14 & 1.6842 \\
8 & feeder7 Sukarno Hatta & 8619 & 130.000 & 15 & 0.9945 \\
9 & feeder14 Panam & 8692 & 130.000 & 28 & 1.872123 \\
10 & feeder26 Settlements & 9884 & 130.000 & 7 & 0.532215 \\
11 & feeder25 Likes Work & 8675 & 130.000 & 12 & 0.800769 \\
\hline \hline
\end{tabular}

\section{III.3. Disturbance Data of Feeder on Rayon Panam}

Data feeder interruption for one year in 2016 include data:

1. Duration of black-out (total length)

2. The frequency of failures (total amount of how much time of black-out)

The data will then be known how long the duration of outages and frequency of failure at each feeder. In calculating the length of time, it will be identified in a matter of minutes, while the failure rate only counts the total number of times each feeder trip or goes out in 2016. The disruption data on the Feeder of Rayon Panam for 2016 can be seen in Table 3.

\section{III.4. SAIFI Calculation and Analysis of Feeder on Panam Rayon}

Based on data from Table 3 and 1, the value of
SAIFI for each feeder can be calculated using Equation 1.

$$
\begin{gathered}
S A I F I=\frac{\text { Frequency of Disturbance } \mathrm{x} \text { Customer in a Feeder }}{\text { Total } \text { of Customer }} \\
\text { SAIFI }=\frac{\sum \lambda i . N i}{\sum N t}
\end{gathered}
$$

Where,

$\lambda i=$ Frequency interference/Failure Score

$N i=$ Number of Subscribers in Feeder

$N t=$ Number of Subscribers in System

From Table 4, it can be seen on every feeder SAIFI different values - different, there is a feeder that has a high-reliability value. Its SAIFI value as belonging to the number of frequency interference that much. But there is also a feeder that has a small SAIFI value; this means that the feeder has a frequency value slightly disorder. SAIFI value can be affected by many frequency disruptions and the number of customers who are on a feeder. In Table 
4 two feeders are included in the category are not reliable because the value of SAIFI both the feeder has a value of SAIFI is high, i.e., feeder Kualu which has a value of SAIFI the most elevated of 6.456 times/customers/year and feeder Stork Way with the benefit of SAIFI amounted to 4.105662 times/customer/year.

\section{III.5. SAIDI Value Calculation and Analysis of Feeder On Panam Rayon}

Based on data from Table 3 and one for each feeder SAIDI value can be calculated using Equation 2.

$$
\begin{gathered}
\text { SAIDI }=\frac{\text { Duration of Disturbance } \mathrm{x} \text { Customer in a Feeder }}{\text { Total of Customer }} \\
\text { SAIFI }=\frac{\sum U \text { U.Ni }}{\sum N t}
\end{gathered}
$$

where, $U i=$ Length Disorders / Length Failure $N i=$ Number of Subscribers In Feeder
$N t=$ Number of Subscribers In System

From Table 5 it can be seen on every feeder SAIDI different values - different, there is a feeder that has a value of high reliability, high in question is its SAIDI value belonging to the total duration for many disorders. But there is also a feeder that has a small SAIDI value, this means that the feeder has a duration of disruptions little value. Effect of duration much interference, affect the value of SAIDI, but not only that, the number of subscribers that are on a feeder also affects the value of SAIDI. If a feeder has a duration of many amount of interference while the number of customers a little bit then it will have little value SAIDI, than when the value of the duration of the disruption slightly while the number of customers who are on a lot of the feeder SAIDI values obtained will be high. From the above table there is a feeder that is included in the category are not reliable, because the feeder SAIDI value is large enough, the feeder Kualu which has the highest SAIDI value of 2.725177 hours/customer/year.

TABLE V

SAIDI OF RAYON PANAM FEEDER

\begin{tabular}{clcccc}
\hline \hline & & \multicolumn{4}{c}{ VALUE SAIDI } \\
\cline { 3 - 6 } No. & \multicolumn{1}{c}{ Name Feeder } & $\mathrm{Ni}$ & $\mathrm{Nt}$ & $\begin{array}{c}\text { Ui } \\
\text { (hours/year) }\end{array}$ & $\begin{array}{c}\text { SAIDI (hours/ } \\
\text { subscriber/year) }\end{array}$ \\
\hline 1 & feeder3 Coast Mirror & 6896 & 130.000 & 1.140 & 0.060473 \\
2 & feeder4 Radish & 14165 & 130.000 & 5.440 & 0.592751 \\
3 & feeder12 Kualu & 16140 & 130.000 & 21.95 & 2.725177 \\
4 & feeder15 Herons Way & 19062 & 130.000 & 11.61 & 1.702383 \\
5 & feeder18 Wildlife Works & 11332 & 130.000 & 9.920 & 0.864719 \\
6 & feeder21 Tarai & 10897 & 130.000 & 14.84 & 1.243934 \\
7 & feeder22 Stadium - UNRI & 15639 & 130.000 & 2.540 & 0.305562 \\
8 & feeder7 Sukarno Hatta & 8619 & 130.000 & 4.20 & 0.278460 \\
9 & feeder14 Panam & 8692 & 130.000 & 5.14 & 0.343668 \\
10 & feeder26 Settlements & 9884 & 130.000 & 0.30 & 0.022809 \\
11 & feeder25 Likes Work & 8675 & 130.000 & 5.00 & 0.027804 \\
\hline \hline
\end{tabular}

\section{III.6. Calculation and Analysis of CAIFI of Panam Rayon Feeder}

Based on data from Table 4 and 5, CAIFI value for each feeder can be determined by using the formula in Equation 4.

$$
C A I F I=\frac{S A I F I}{S A I D I}
$$

Based on Equation 4, it can be seen the value of its CAIFI on each feeder that can be seen in Table 6 that there is some feeder experiencing CAIFI very high cost. Value - the value exceeds the importance of other feeders. Feeder 3 Pantai Cermin has a CAIFI value of 22.80702 times/hour/year and 26 Settlements Feeder that has a value of 23.33333 CAIFI times/hour/year. It is influenced by SAIDI values that are not directly proportional to the amount of SAIFI. SAIDI value obtained is very much lower than the amount of SAIFI, so if doing a calculation for CAIFI value, resulting in CAIFI great value. 
TABLE VI

CAIFI OF RAYON PANAM FEEDER

\begin{tabular}{clccc}
\hline \hline \multirow{2}{*}{ No. } & \multicolumn{1}{c}{ Name feeder } & $\begin{array}{c}\text { SAIFI (times/ } \\
\text { subscriber/year) }\end{array}$ & $\begin{array}{c}\text { SAIDI (hours/ } \\
\text { subscriber/year) }\end{array}$ & $\begin{array}{c}\text { CAIFI (time/ } \\
\text { hours/year) }\end{array}$ \\
\cline { 3 - 5 } 1 & feeder3 Coast Mirror & 1.37920 & 0.06047 & 22.8070 \\
2 & feeder4 Radish & 1.19858 & 0.59275 & 2.02206 \\
3 & feeder12 Kualu & 6.45600 & 2.72518 & 2.36902 \\
4 & feeder15 Herons Way & 4.10566 & 1.70238 & 2.41171 \\
5 & feeder18 Wildlife Works & 2.17923 & 0.86472 & 2.52016 \\
6 & feeder21 Tarai & 2.93381 & 1.24393 & 2.35849 \\
7 & feeder22 Stadium - UNRI & 1.68420 & 0.30556 & 5.51181 \\
8 & feeder7 Sukarno Hatta & 0.99450 & 0.27846 & 3.57143 \\
9 & feeder14 Panam & 1.87212 & 0.34367 & 5.44747 \\
10 & feeder26 Settlements & 0.53222 & 0.02281 & 23.3333 \\
11 & feeder25 Likes Work & 0.80077 & 0.02780 & 28.8000 \\
\hline \hline
\end{tabular}

TABLE VII

CAIDI OF RAYON PANAM FEEDER

\begin{tabular}{clccc}
\hline \hline \multirow{2}{*}{ No. } & Name feeder & \multicolumn{3}{c}{ VALUE CAIDI } \\
\cline { 3 - 5 } & & SAIFI (times/ subscriber/year) & $\begin{array}{c}\text { SAIDI } \\
\text { (hours/ subscriber/year) }\end{array}$ & $\begin{array}{c}\text { CAIDI } \\
\text { (hours/ times/year) }\end{array}$ \\
\hline 1 & feeder3 Coast Mirror & 1.37920 & 0.060473 & 0.04385 \\
2 & feeder4 Radish & 1.19858 & 0.592751 & 0.49455 \\
3 & feeder12 Kualu & 6.45600 & 2.725177 & 0.42212 \\
4 & feeder15 Herons Way & 4.10566 & 1.702383 & 0.41464 \\
5 & feeder18 Wildlife Works & 2.17923 & 0.864719 & 0.39680 \\
6 & feeder21 Tarai & 2.93381 & 1.243934 & 0.42400 \\
7 & feeder22 Stadium - UNRI & 1.68420 & 0.305562 & 0.18143 \\
8 & feeder7 Sukarno Hatta & 0.99450 & 0.278460 & 0.28000 \\
9 & feeder14 Panam & 1.87212 & 0.343668 & 0.18357 \\
10 & feeder26 Settlements & 0.53222 & 0.022809 & 0.04286 \\
11 & feeder25 Likes Work & 0.80077 & 0.027804 & 0.03472 \\
\hline \hline
\end{tabular}

\section{III.7. Calculation and Analysis of Value CAIDI Feeder On Panam Rayon}

Based on data from Table 4 and 5, CAIDI value for each feeder can be determined by using the formula in Equation 4.

$$
C A I D I=\frac{S A I D I}{S A I F I}
$$

Based on Equation 4, it can obtained the value of CAIDI by performing calculations on each feeder it can be seen in Table 7 that the values CAIDI obtained can be considered reliable because of its value to reach the target that has been set by the IEEE std 1366-2003 amounted to 1:47 hours/times/year.

\section{III.8. Effect of Impaired Operation Against Network Reliability}

The value of reliability can be determined by calculating several aspects such as SAIFI and
SAIDI. Both of these aspects is used as a reference to assess how much value the reliability of a not distribution. To calculate this aspect takes several factors in order to determine whether the value of SAIFI and SAIDI can be said to be reliable. SAIFI and SAIDI can be determined from the distractions of operations that occur. This disorder can be frequency interference or say how much disruption that occurs on a feeder and duration of the disruption.

There are two factors causing faults in operating i.e., internal factors and external factors. Internal factors generally permanent, such equipment does not match the standard set, installation of equipment that is not appropriate or wrong and aging equipment. If the internal disturbance occurs it will affect the number of customers being extinguished, the more equipment is damaged, the customer outages will be growing, and this will have an impact on the value of SAIFI. While external factors, namely weather such as rain, high winds, earthquakes and lightning, living organisms, for example humans, animals and plants. These disturbances will affect the duration of the 
interruption, because this disorder require considerable time to return to normal state. So it will have an impact on the value of SAIDI.

Therefore, interruption of operations greatly affect the reliability of the network. If the reliability of a network distribution system is not good then the continuity of electricity waiter to customer can be said is not good anyway. To overcome that continuity of service can be served well, then the response by installing equipment in order to reduce the poor service to consumers. Such equipment as Recloser, Recloser function as a useful tool in the event of disruption to the Recloser will work to restore normal services after disruption by the not too distant future. Then LBS (Load Break Switch) is useful as a barrier and fault location This tool also functions as a switch between the feeder circuit to the other feeders in an emergency on a primary distribution network operating system type circumference (Loop / ring). So that the continuity of electrical service can still be served well despite the distractions.

\section{III.9. Comparison Values With SPLN No. 68-2 SAIFI 1986 and IEEE std 1366-2003}

Based on SAIFI values obtained in Table 4, it can be compared to the value in SPLN No. 68-2, 1986, with a target of 3.2 times/customers/year and IEEE std. 1366-2003 with a target of 1.45 times/customer/year. Is Rayon Panam distribution network in each feeder has reached the predetermined targets or have not yet reached the target can be seen in terms of the charter Table 8

Each feeder has SAIFI values are different, this is because the disturbance on each feeder is different. After calculating the importance of the two feeder Rayon Panam experiencing high or SAIFI value of the target SPLN 68-2 No. 1986. Feeder - feeder experiencing a low level of reliability is that the feeder 12 Kualu with SAIFI value of 6.456 times/customer/year, and Feeder 15 Herons Way with SAIFI value of 4.105 .662 times/customer/year. Since both of these experienced feeder SAIFI value that exceeds the target SPLN No. 68-2 in 1986 amounted to 3.2 times/customer/year, then the second is said to be unreliable feeder. As for the value SAIFI targeted by IEEE std 1366-2003 of 1.45 times/customer/year.

Based on Table 8 it can be seen that there are six feeders that have SAIFI value that is not in accordance with IEEE std 1366-2003 targets. Feeder - the feeder is a feeder 12 Kualu with SAIFI value of 6.456 times/customer/year, feeder 15 Herons Way with SAIFI value of 4.105662 times/customer/year, feeder 18 Garden work with SAIFI value of 2.179231 times/customer/year, feeder 21 Tarai with SAIFI value of 2.933808 times/customer/year, 22 Stadion feeder SAIFI value of Riau with 1.6842 times/customer/year, feeder 14 Panam with SAIFI value of 1.872123 times/customer/year. Feeder - The feeder can be said to be not reliable according to IEEE std 13662003 standard because it does not reach the set targets.

TABLE VIII

COMPARISON VALUES WITH SPLN NO. 68-2 SAIFI 1986 AND IEEE STD 1366-2003

\begin{tabular}{ccccccc}
\multicolumn{6}{c}{ COMPARISON VALUES WITH SPLN NO. 68-2 SAIFI 1986 AND IEEE STD 1366-2003 } \\
\cline { 3 - 5 } No. & feeder & SAIFI & $\begin{array}{c}\text { SAIFI 3.2 } \\
(\mathrm{k} / \mathrm{p} / \mathrm{t})\end{array}$ & $\begin{array}{c}\text { SAIFI 1.45 } \\
(\mathrm{k} / \mathrm{p} / \mathrm{t})\end{array}$ & $\begin{array}{c}\text { Number of } \\
\text { Subscribers }\end{array}$ & Length Channels \\
\cline { 3 - 6 } & feeder3 & 1.3792 & $\sqrt{ }$ & $\sqrt{ }$ & 6896 & 94.8 \\
2 & feeder 4 & 1.19858 & $\sqrt{ }$ & $\sqrt{ }$ & 14165 & 41.11 \\
3 & feeder12 & 6.456 & $\mathrm{x}$ & $\mathrm{x}$ & 16140 & 64.34 \\
4 & feeder15 & 4.10566 & $\mathrm{x}$ & $\mathrm{x}$ & 19062 & 51.5 \\
5 & feeder18 & 2.17923 & $\sqrt{ }$ & $\mathrm{x}$ & 11332 & 22.65 \\
6 & feeder21 & 2.93381 & $\sqrt{ }$ & $\mathrm{x}$ & 10897 & 86.18 \\
7 & feeder22 & 1.6842 & $\sqrt{ }$ & $\mathrm{x}$ & 15639 & 27.18 \\
8 & feeder7 & 0.9945 & $\sqrt{ }$ & $\sqrt{ }$ & 8619 & 21.3 \\
9 & feeder14 & 1.87212 & $\sqrt{ }$ & $\mathrm{x}$ & 8692 & 25.33 \\
10 & feeder26 & 0.53222 & $\sqrt{ }$ & $\sqrt{ }$ & 9884 & 59.19 \\
11 & feeder25 & 0.80077 & $\sqrt{ }$ & $\sqrt{ }$ & 8675 & 36.16 \\
\hline \hline
\end{tabular}

\section{III.10. Comparison Values With SPLN No. 68-2 SAIDI 1986 and IEEE std 1366-2003}

Based on SAIDI values obtained in Table 5, it can be compared with the value of SPLN No. 68-2 in 1986 with a target of 21.09 hours/customer/year and IEEE std 1366-2003 with a target of 2.3 hours/customer/year. Is Rayon Panam distribution network in each feeder has reached the predetermined targets or not that can be seen from 
Table 9.

Based on Table 9 it can be seen that the entire feeder exist in Panam Rayon has reached the target set by SPLN No. 68-2, 1986. The market value of SAIDI targeted by IEEE std 1366-2003 amounted to 2.3 hours/customer/year. After calculation of the obtained results as shown in Table 9. There is one feeder that has a value of SAIDI are not in accordance with IEEE std 1366-2003 targets. The feeder is a feeder 12 Kualu with SAIDI value of 2.725177 hours/customer/year. The feeder can be said to be not reliable according to IEEE std 13662003 standard because it does not reach the set targets.

\section{III.11.Analysis EENS (Expected energy not supplied)}

Data of EENS (Expected energy not supplied) in the form of energy data that can not be distributed by each feeder in one year. From these data it will be known how much harm has been gained because energy can not be transmitted. Table 10 is a data EENS (Expected energy not supplied) every feeder Rayon Panam 2016.

Based on Table 10 it can be seen that the value EENS (Expected energy not supplied), the largest found in the feeder 12 Kualu amounted to 93.934 $\mathrm{kWh} /$ year. As for EENS (Expected energy not supplied), the smallest found on the feeder 26 Settlements of $1,449 \mathrm{kWh} /$ year. Large or small EENS (Expected energy not supplied) can be influenced by the amount of interference frequency and duration of interruption. The more the number of frequency interference and interruption duration, the number EENS (Expected energy not supplied) will be greater, and vice versa if the fewer number of frequency interference and interruption duration, the number EENS (Expected energy not supplied) will be small.

TABLE IX

COMPARISON VALUE SAIDI WITH SPLN No. 68-2 1986 AND IEEE STD 1366-2003

\begin{tabular}{|c|c|c|c|c|c|c|}
\hline \multirow[b]{2}{*}{ No. } & \multirow[b]{2}{*}{ feeder } & \multirow{2}{*}{$\frac{\text { Reliability Index }}{\text { SAIDI }}$} & \multirow{2}{*}{$\begin{array}{c}\text { SPLN } \\
\text { SAIDI } 21.09 \\
(\mathrm{j} / \mathrm{p} / \mathrm{t})\end{array}$} & \multirow{2}{*}{$\begin{array}{c}\text { IEEE } \\
\text { SAIDI } 2.3 \\
(\mathrm{j} / \mathrm{p} / \mathrm{t})\end{array}$} & \multirow[b]{2}{*}{$\begin{array}{l}\text { number of } \\
\text { Subscribers }\end{array}$} & \multirow[b]{2}{*}{ Length Channels } \\
\hline & & & & & & \\
\hline 1 & feeder3 & 0.06047 & $\sqrt{ }$ & $\sqrt{ }$ & 6896 & 94.80 \\
\hline 2 & feeder4 & 0.59275 & $\sqrt{ }$ & $\sqrt{ }$ & 14165 & 41.11 \\
\hline 3 & feeder 12 & 2.72518 & $\sqrt{ }$ & $\mathrm{x}$ & 16140 & 64.34 \\
\hline 4 & feeder 15 & 1.70238 & $\sqrt{ }$ & $\sqrt{ }$ & 19062 & 51.5 \\
\hline 5 & feeder 18 & 0.86472 & $\sqrt{ }$ & $\sqrt{ }$ & 11332 & 22.65 \\
\hline 6 & feeder 21 & 1.24393 & $\sqrt{ }$ & $\sqrt{ }$ & 10897 & 86.18 \\
\hline 7 & feeder 22 & 0.30556 & $\sqrt{ }$ & $\sqrt{ }$ & 15639 & 27.18 \\
\hline 8 & feeder7 & 0.27846 & $\sqrt{ }$ & $\sqrt{ }$ & 8619 & 21.30 \\
\hline 9 & feeder 14 & 0.34367 & $\sqrt{ }$ & $\sqrt{ }$ & 8692 & 25.33 \\
\hline 10 & feeder 26 & 0.02281 & $\sqrt{ }$ & $\sqrt{ }$ & 9884 & 59.19 \\
\hline 11 & feeder 25 & 0.02780 & $\sqrt{ }$ & $\sqrt{ }$ & 8675 & 36.16 \\
\hline
\end{tabular}

TABLE X

VALUE EENS AND AENS FEEDER ON RAYON PANAM

\begin{tabular}{rlccc}
\hline \hline \multirow{2}{*}{ No. } & & \multicolumn{4}{c}{ Name feeder } & \multicolumn{2}{c}{ AENS $($ Average energy not supplied) } \\
\cline { 3 - 5 } & & $\begin{array}{c}\text { The number } \\
\text { of subscribers }\end{array}$ & $\begin{array}{c}\text { EENS } \\
\text { KWh/year }\end{array}$ & $\begin{array}{c}\text { AENS } \\
\text { KWh/customer/year }\end{array}$ \\
\hline 1 & feeder3 Coast Mirror & 6896 & 2524 & 0.36601 \\
2 & feeder4 Radish & 14165 & 32067 & 2.26382 \\
3 & feeder12 Kualu & 16140 & 93934 & 5.81995 \\
4 & feeder15 Herons Way & 19062 & 90136 & 4.72857 \\
5 & feeder18 Wildlife Works & 11332 & 51595 & 4.55304 \\
6 & feeder21 Tarai & 10897 & 67573 & 6.20106 \\
7 & feeder22 Stadium - UNRI & 15639 & 5711 & 0.36518 \\
8 & feeder7 Sukarno Hatta & 8619 & 13353 & 1.54925 \\
9 & feeder14 Panam & 8692 & 11032 & 1.26921 \\
10 & feeder26 Settlements & 9884 & 1449 & 0.14660 \\
11 & feeder25 Likes Work & 8675 & 3777 & 0.43539 \\
\hline \hline
\end{tabular}

While the value - average total of AENS (Average energy not supplied) is obtained, which reached $6.2010645 \mathrm{kWh} /$ customer/year. AENS value (Average energy not supplied) obtained from the total EENS (Expected energy not supplied) for one year each feeder divided by the total number of subscribers feeder. 


\section{Conclusion}

Based on calculations SAIFI value, the entire feeder in Panam Rayon has not met the standards SPLN 68-2: SAIFI in 1986 that is by 3.2 times/ customer/year. The feeder is a feeder 12 Kualu of 6.456 times/customers/year and 15 Herons Way Feeder at 4.105662 times/customer/year. As for the standard IEEE std 1366 - 2003 is to SAIFI 1:45 time/customer/year No 6 feeders that do not fit into its standard feeder 12 Kualu of 6.456 times/customer/year, feeder 15 Herons Way of 4.105662 times/customer/years, the feeder 18 Wildlife Works at 2.179231 times/customer/year, feeder 21 Tarai at 2.933808 times/customer/year, feeder 22 Stadium - UNRI of 1.6842 times/customers/year and feeder 14 Panam by 1.872123 times/customer/year. Feeder - feeders that do not reach the standards that can not reliable. Factor number of customers and long-lines also affects the value of SAIFI. SAIDI value calculation based on each feeder in Panam Rayon, the entire feeder has met the standards SPLN 68-2: 1986 is the SAIDI 21.09 hour/customer/year and for the standard of IEEE std 1366-2003 is the SAIDI 2.3 hours/customer/year No one who experienced feeder SAIDI values outside the standard IEEE std 1366 - 2003 is feeder 12 Kualu amounted to 2.725177 hours/customer/year.

\section{References}

[1] P. Kundur, Power System Stability and Control, Toronto, ON, Canada:McGraw-Hill, 1993.

[2] P. Krause, O. Wasynczuk, S. Sudhoff, S. Pekarek, Analysis of Electric Machinery and Drive Systems, Hoboken, NJ, USA:Wiley, 2013.

[3] J. O. Aibangbee, Bells, Ota, "Power Transformer Inrush Current Detection \& Harmonic Sharing In Differential Relay Protection", International Journal of Engineering Trends and Technology (IJETT), vol. 33, March 2016.

[4] A. Dawn. 2015. Analysis of Electric Power Distribution System Reliability IN PTPLN UPJ Rayon Brits (Thesis). Yogyakarta: Yogyakarta Muhammadiyah University.

[5] O.D. Bagus. "Network Reliability Analysis of Medium Voltage Distribution 20KV system in PT.Astra Daihatsu Motor". Electrical engineering major. niversitas Mercubuana. Jakarta. 2013.

[6] H. Endra. 2011. Evaluation and Study of Distribution Network Reliability $4 \mathrm{KV}$ Lex Plant Santan Terminal, Chevron Indonesia Company(Thesis). Yogyakarta: Gadjah Mada University.

\section{Authors' information}

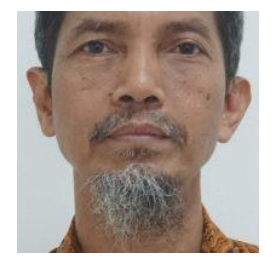

Slamet Suripto obtained his B.Eng. in Electrical Engineering from the University of Gajah Mada, Indonesia. His Master study was done at the Electrical Engineering, Gadjah Mada University, Indonesia. She currently is a lecture in the department of electrical engineering, University of Muhammadiyah Yogyakarta.

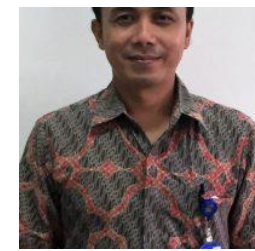

Rahmat Adiprasetya Al Hasibi obtained his B.Eng. in Electrical Engineering from the University of Gajah Mada, Indonesia, His Master study was done at the Electrical Engineering, Gadjah Mada University, Indonesia. He currently is a lecture in the department of electrical engineering, University of Muhammadiyah Yogyakarta.

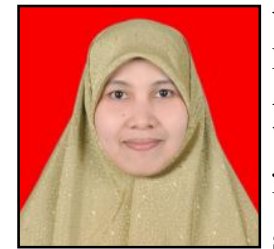

Yessi Jusman obtained her B.Eng. in Electrical and Electronic Engineering from Andalas University, Indonesia in 2007. She worked as a Research Assistant started in July 2008 until November 2009 in Universiti Sains Malaysia. Her Master study was done at 2012 at the School of Electrical and Electronic Engineering, USM Engineering Campus in Nibong Tebal, Penang, Malaysia. She was finished her $\mathrm{PhD}$ degree in 2016 at the University of Malaya with specializes in Image, Signal Processing, and algorithms. She currently is a lecture in the department of electrical engineering, University of Muhammadiyah Yogyakarta.

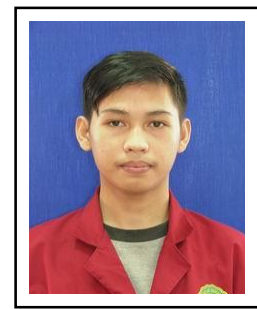

Muhammad Rusydi Al Aroffi obtained his B.Eng. in Electrical Engineering from the University of Muhammadiyah Yogyakarta, Indonesia in 2017.

His main research interest is in powe sistem analysis and power system reliability.

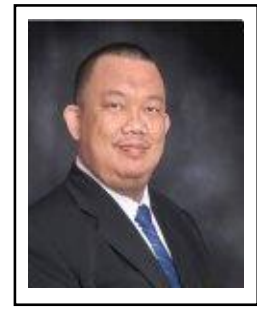

Jamaaluddin obtained his B.Eng. in Electrical Engineering from Universitas Brawijaya, Malang, Indonesia, in 1993. His Master study was done at the Master of Management from Universitas Muhammadiyah Yogyakarta. $\mathrm{He}$ currently is a lecture in Department of Electrical Engineering, Universitas Muhammadiyah Sidoarjo. His main research interest is in powe sistem analysis, energy audit, energy conversion, power electronics, and power system control, and load forecasting. 